\title{
Evaluation of Sacroiliac Joint Interventions: A Systematic Appraisal of the Literature
}

Matthew P. Rupert, MD, MS1, Marion Lee, MD², Laxmaiah Manchikanti, MD², Sukdeb Datta, MD', and Steven P. Cohen, MD

From: ${ }^{1}$ Vanderbilt Interventional Pain Center Cool Springs, Cool Springs Surgery Center, Franklin, TN; ${ }^{2}$ The Pain Center at Affinity Health Group, Tifton, GA; ${ }^{3}$ Pain Management Center of Paducah, Paducah, $\mathrm{KY} ;{ }^{4}$ Vanderbilt University Medical Center, Nashville, $\mathrm{TN}$; and ${ }^{5}$ Johns Hopkins School of Medicine, Baltimore, MD

Dr. Rupert is Assistant Professor of Interventional Pain Management, Vanderbilt Interventional Pain Center

Cool Springs, Cool Springs Surgery Center, Franklin, TN. Dr. Lee is Director of The Pain Center at Affinity Health Group, Tifton, GA. Dr. Manchikanti is Medical Director of the Pain Management Center of Paducah, Paducah, KY, and Associate Clinical Professor of Anesthesiology and Perioperative Medicine, University of Louisville, Louisville, KY. Dr. Datta is Director, Vanderbilt University Interventional Pain Program, Associate Professor, Dept. of Anesthesiology Vanderbilt University Medica

Center, Nashville, TN. Dr. Cohen is Associate Professor, Department of Anesthesiology and Critical Care Medicine, Pain Management Division, Johns Hopkins School of Medicine Baltimore, MD, and Walter Reed Army

Medical Center, Washington, DC

Address correspondence: Matthew P. Rupert, MD, MS Vanderbilt Interventional Pain Center Cool Springs Cool Springs Surgery Center 2009 Mallory Lane, Suite 250 Franklin, TN 37067

E-mail:mattrupert@comcast.net

Disclaimer: Dr. Datta receives research support from Sucampo Pharmaceuticals and an honorarium from Smith and Nephew. Conflict of interest: None.

Manuscript received: 01/18/2008 Accepted for publication: 01/25/2009

Free full manuscript: www.painphysicianjournal.com
Background: The sacroiliac joint has been implicated as a source of low back and lower extremity pain. There are no definite historical, physical, or radiological features that can definitively establish a diagnosis of sacroiliac joint pain. Based on the present knowledge, an accurate diagnosis is made only by controlled sacroiliac joint diagnostic blocks. The sacroiliac joint has been shown to be a source of pain in $10 \%$ to $27 \%$ of suspected patients with chronic low back pain utilizing controlled comparative local anesthetic blocks.

Study Design: A systematic review of diagnostic and therapeutic sacroiliac joint interventions.

Objective: To evaluate the accuracy of diagnostic sacroiliac joint interventions and the utility of therapeutic sacroiliac joint interventions.

Methods: The literature search was carried out by searching the databases of PubMed, EMBASE, and Cochrane reviews.

Methodologic quality assessment of included studies was performed using the Agency for Healthcare Research and Quality (AHRQ) methodologic quality criteria for diagnostic accuracy and observational studies, whereas randomized trials were evaluated utilizing the Cochrane review criteria. Only studies with scores of 50 or higher were included for assessment.

Level of evidence was based on the U.S. Preventive Services Task Force (USPSTF) criteria

Outcome Measures: For diagnostic interventions, the outcome criteria included at least $50 \%$ pain relief coupled with a patient's ability to perform previously painful maneuvers with sustained relief using placebo-controlled or comparative local anesthetic blocks.

For therapeutic purposes, outcomes included significant pain relief and improvement in function and other parameters. Short-term relief for therapeutic interventions was defined as 6 months or less, whereas long-term effectiveness was defined as greater than 6 months.

Results: The indicated level of evidence is II-2 for the diagnosis of sacroiliac joint pain utilizing comparative, controlled local anesthetic blocks. The prevalence of sacroiliac joint pain is estimated to range between $10 \%$ and $38 \%$ using a double block paradigm in the study population. The false-positive rate of single, uncontrolled, sacroiliac joint injections is $20 \%$ to $54 \%$.

The evidence for provocative testing to diagnose sacroiliac joint pain is Level II-3 or limited.

For radiofrequency neurotomy the indicated evidence is limited (Level II-3) for short- and longterm relief.

Limitations: The limitations of this systematic review include the paucity of literature evaluating the role of both diagnostic and therapeutic interventions and widespread methodological flaws.

Conclusions: The indicated evidence for the validity of diagnostic sacroiliac joint injections is Level II-2. The evidence for the accuracy of provocative maneuvers in the diagnosing of sacroiliac joint pain is limited (Level II-3). The evidence for radiofrequency neurotomy is also limited (Level II-3).

Key words: Chronic low back pain, sacroiliac joint pain, sacroiliitis, sacroiliac joint injection, sacroiliac joint dysfunction, thermal radiofrequency, pulsed radiofrequency

Pain Physician 2009; 12:399-418 


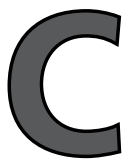

ontrolled studies have established intervertebral discs, facet joints, and sacroiliac joints as potential sources of low back and lower extremity pain (1-13). The sacroiliac joint is accepted as a potential source of low back and/or buttock pain with or without lower extremity pain. The sacroiliac joint has been implicated as the primary source of pain (1-8) in $10 \%$ to $27 \%(4,9,10)$ of patients with suspected sacroiliac joint pain utilizing controlled comparative local anesthetic blocks.

The sacroiliac joint is a diarthrodial joint, receiving innervation from the lumbosacral nerve roots (14-23). Neurophysiologic studies have demonstrated both nociceptive and proprioceptive afferent units in the sacroiliac joint $(19,20,24)$. Referral patterns based on sacroiliac joint provocation and analgesic response to local anesthetics have been published in asymptomatic volunteers $(25)$ and patients with pain $(26,27)$.

There is no universally accepted gold standard for the diagnosis of low back pain stemming from the sacroiliac joint(s), intervertebral disc(s), or facet joint(s) (28). The recommended reference standards involve anesthetic or provocative injections (13). Multiple arguments have been made in favor and against the diagnostic accuracy of controlled local anesthetic blocks (1-8,12,28-35). However, controlled local anesthetic blocks continue to be the best available tool to identify either the intervertebral discs, facet, or sacroiliac joints as the source of low back pain $(1-3,13,28)$. Yet, these reference standards are invasive, expensive, and often difficult to interpret, and therefore may not be suitable for routine clinical use.

In a systematic review evaluating a battery of tests to identify the disc, sacroiliac joint, or facet joint as the source of low back pain, Hancock et al (28) suggested that a combination of sacroiliac joint pain provocative maneuvers appears to be useful in pinpointing the sacroiliac joint as the principal source of symptoms in patients with pain below the 5 th lumbar vertebra. They also concluded that although a positive bone scan has high specificity, it is associated with a very low sensitivity, which means that the majority of patients with the sacroiliac joint pain will not be accurately identified.

A systematic review by Szadek et al (36), evaluated the diagnostic validity of the International Association for the Study of Pain (IASP) criteria for sacroiliac joint pain. The meta-analysis showed that the thigh thrust test, the compression test, and 3 or more positive stressing tests contain sufficient discriminative power for diagnosing sacroiliac joint pain. They concluded that in view of the lack of a gold standard for sacroiliac joint pain, the diagnostic validity of tests for sacroiliac joint pain should be regarded with caution.

Song et al (37) performed a systematic literature review evaluating the diagnostic value of scintigraphy in assessing sacroiliitis and ankylosing spondylitis. They concluded that scintigraphy is at best of limited value in establishing a diagnosis of ankylosing spondylitis. Two systematic reviews evaluated the role of diagnostic intraarticular injections $(1,2)$ in establishing the sacroiliac joint(s) as the primary pain generator. Both reviews concluded the specificity and validity to be moderate. In a best-evidence review of diagnostic procedures for neck and low back pain that focused on previously published systematic reviews $(1,2,28)$, Rubinstein and van Tulder (38) also concluded that there was moderate evidence for diagnostic sacroiliac joint blocks.

Sacroiliac joint pain may be managed by intraarticular injections or neurolysis of the nerve supply. However, 2 previous systematic reviews $(1,2)$ found the evidence supporting therapeutic sacroiliac joint interventions to be limited. European guidelines for the management of chronic non-specific low back pain (39) evaluating the literature through 2002 also concluded that there is limited evidence supporting sacroiliac joint injections with corticosteroids. But despite the absence of any clear consensus in favor of sacroiliac joint interventions, their use has continued to grow in recent years (40-42).

The purpose of this review is to systematically assess the literature on diagnostic and therapeutic sacroiliac joint interventions.

\section{Methods}

The literature search included the databases PubMed, EMBASE, and Cochrane reviews; systematic and narrative reviews; and the NIH clinical trials registry. The search included articles published between 1966 and 2008. A manual review of the reference section of selected articles was then performed to identify relevant studies missed in the electronic search. Only English language articles were reviewed.

The search was conducted utilizing the following terms: sacroiliac joint, sacroiliac joint pain, sacroiliac joint injections, radiofrequency neurotomy of sacroiliac joint, neurolytic blocks of sacroiliac joint. 


\section{Diagnostic Sacroiliac Joint Interventions}

\section{Inclusion Criteria}

Diagnostic sacroiliac joint interventions in patients with chronic low back and/or lower extremity pain for greater than 3 months in duration were analyzed for review. Only those studies utilizing fluoroscopically guided controlled diagnostic blocks (i.e., placebo-controlled or comparative local anesthetic) were included. The criterion standard for diagnosis of sacroiliac joint pain was $50 \%$ or greater pain relief for the duration of action of the local anesthetic, coupled with increased ability to perform previously painful movements.

Excluded from analysis were studies done on animals, cadavers, ultrasound guided injections, case reports, book chapters, non-evidence-based guidelines, letters to the editor, and expert opinion papers.

\section{Method of Review}

All abstracts obtained from computerized database searches were screened for inclusion. Two physician reviewers evaluated articles meeting inclusion criteria for methodologic quality using the modified Agency for Healthcare Research and Quality (AHRQ) criteria for diagnostic studies (43).

The quality of individual articles was evaluated using the above criteria with application of consensusbased weighted scores developed by the guidelines committee of the American Society of Interventional Pain Physicians (ASIPP) (33). These guidelines have been utilized in other systematic reviews $(44,45)$ and have recently been refined and modified (46-50). Only studies scoring at least 50 out of 100 were included for analysis.

Each study was evaluated by 2 physicians for the stated criteria with any disagreements resolved by a third physician. If there was a conflict of interest with the reviewed manuscripts with authorship or any other type of conflict, the involved authors did not review the manuscripts for quality assessment, clinical relevance, evidence synthesis, or grading of evidence.

\section{Analysis of Evidence}

Qualitative analysis was conducted using 5 levels of evidence, ranging from Level I to III with 3 subcategories in Level II, as illustrated in Table 1 (51).

\section{Therapeutic Sacroiliac Joint Interventions}

\section{Inclusion Criteria}

Studies should have documented the existence of sacroiliac joint pain using controlled sacroiliac joint blocks. Two types of SI joint interventions were included in this review: intraarticular sacroiliac joint injections and radiofrequency neurotomy of the nerve supply to the sacroiliac joint. All studies must have documented outcome evaluations extending at least 6 months, with appropriate statistical analysis.

Studies done without appropriate diagnostic methods (i.e., minimizing false-positive responses, non-systematic reviews, book chapters, and case reports were excluded.

\section{Outcome Parameters}

The primary outcome measure was pain relief at various time points documented over a period lasting

Table 1. Modified quality of evidence developed by USPSTF.

\begin{tabular}{|c|l||}
\hline I: & Evidence obtained from multiple properly conducted diagnostic accuracy studies. \\
\hline II-1: & Evidence obtained from at least one properly conducted diagnostic accuracy study of adequate size. \\
\hline II-2: & Evidence obtained from at least one properly designed small diagnostic accuracy study. \\
\hline II-3: & Evidence obtained from diagnostic studies of uncertainty. \\
\hline III: & Opinions of respected authorities, based on clinical experience descriptive studies and case reports or reports of expert committees. \\
\hline
\end{tabular}

Adapted from the U.S. Preventive Services Task Force (USPSTF) (51). 
at least 6 months. Secondary outcome measures were functional improvement, psychological improvement, return-to-work, opioid use, and complications. Shortterm relief was defined as relief lasting 6 months or less and long-term relief as benefits extending beyond 6 months.

\section{Methodologic Quality Assessment}

The quality of each individual article used in this analysis was assessed by modified Cochrane review criteria with weighted scores (52) for randomized trials and AHRQ quality criteria for assessment for observational studies (43) with consensus-based weighted scoring developed by the guidelines committee of ASIPP (33) and used in other systematic reviews (44,4750,53-61). Only studies scoring at least 50 out of 100 were included for analysis.

Each study was evaluated by 2 physicians for the stated criteria with any disagreements resolved by a third physician. If there was a conflict of interest with the reviewed manuscripts with authorship or any other type of conflict, the involved authors did not re- view the manuscripts for quality assessment, clinical relevance, evidence synthesis, or grading of evidence.

\section{Analysis of Evidence}

Qualitative analysis was conducted using 5 levels of evidence, ranging from Level I to III with 3 subcategories in Level II, as illustrated in Table 1 (51).

\section{Recommendations}

Grading recommendations were based on Guyatt et al's criteria with 6 Levels, $1 \mathrm{~A}-1 \mathrm{C}$ strong and 2A - 2C weak as illustrated in Table 2 (62).

\section{Results}

\section{Diagnostic Studies}

\section{Literature Search}

Our comprehensive search yielded 2,260 articles for review on sacroiliac joint pain (Fig. 1). However, only 13 studies were considered for inclusion.

The following studies were excluded for failure

Table 2. Grading recommendations.

\begin{tabular}{|c|c|c|c|}
\hline $\begin{array}{l}\text { Grade of Recommendation/ } \\
\text { Description }\end{array}$ & $\begin{array}{l}\text { Benefit vs Risk and } \\
\text { Burdens }\end{array}$ & $\begin{array}{l}\text { Methodological Quality of } \\
\text { Supporting Evidence }\end{array}$ & Implications \\
\hline $\begin{array}{l}\text { 1A/strong recommendation, } \\
\text { high-quality evidence }\end{array}$ & $\begin{array}{l}\text { Benefits clearly outweigh } \\
\text { risk and burdens, or vice } \\
\text { versa }\end{array}$ & $\begin{array}{l}\text { RCTs without important limitations } \\
\text { or overwhelming evidence from } \\
\text { observational studies }\end{array}$ & $\begin{array}{l}\text { Strong recommendation, can apply } \\
\text { to most patients in most circum- } \\
\text { stances without reservation }\end{array}$ \\
\hline $\begin{array}{l}1 \mathrm{~B} / \text { strong recommendation, } \\
\text { moderate quality evidence }\end{array}$ & $\begin{array}{l}\text { Benefits clearly outweigh } \\
\text { risk and burdens, or vice } \\
\text { versa }\end{array}$ & $\begin{array}{l}\text { RCTs with important limitations } \\
\text { (inconsistent results, methodologi- } \\
\text { cal flaws, indirect, or imprecise) or } \\
\text { exceptionally strong evidence from } \\
\text { observational studies }\end{array}$ & $\begin{array}{l}\text { Strong recommendation, can apply } \\
\text { to most patients in most circum- } \\
\text { stances without reservation }\end{array}$ \\
\hline $\begin{array}{l}1 \mathrm{C} / \text { strong recommendation, } \\
\text { low-quality or very low-quality } \\
\text { evidence }\end{array}$ & $\begin{array}{l}\text { Benefits clearly outweigh } \\
\text { risk and burdens, or vice } \\
\text { versa }\end{array}$ & Observational studies or case series & $\begin{array}{l}\text { Strong recommendation but may } \\
\text { change when higher quality evi- } \\
\text { dence becomes available }\end{array}$ \\
\hline $\begin{array}{l}\text { 2A/weak recommendation, high- } \\
\text { quality evidence }\end{array}$ & $\begin{array}{l}\text { Benefits closely balanced } \\
\text { with risks and burden }\end{array}$ & $\begin{array}{l}\text { RCTs without important limitations } \\
\text { or overwhelming evidence from } \\
\text { observational studies }\end{array}$ & $\begin{array}{l}\text { Weak recommendation, best action } \\
\text { may differ depending on circum- } \\
\text { stances or patients' or societal } \\
\text { values }\end{array}$ \\
\hline $\begin{array}{l}2 \mathrm{~B} / \text { weak recommendation, } \\
\text { moderate-quality evidence }\end{array}$ & $\begin{array}{l}\text { Benefits closely balanced } \\
\text { with risks and burden }\end{array}$ & $\begin{array}{l}\text { RCTs with important limitations } \\
\text { (inconsistent results, methodologi- } \\
\text { cal flaws, indirect, or imprecise) or } \\
\text { exceptionally strong evidence from } \\
\text { observational studies }\end{array}$ & $\begin{array}{l}\text { Weak recommendation, best action } \\
\text { may differ depending on circum- } \\
\text { stances or patients' or societal } \\
\text { values }\end{array}$ \\
\hline $\begin{array}{l}2 \mathrm{C} / \text { weak recommendation, } \\
\text { low-quality or very low-quality } \\
\text { evidence }\end{array}$ & $\begin{array}{l}\text { Uncertainty in the estimates } \\
\text { of benefits, risks, and burden; } \\
\text { benefits, risk, and burden } \\
\text { may be closely balanced }\end{array}$ & Observational studies or case series & $\begin{array}{l}\text { Very weak recommendations; } \\
\text { other alternatives may be equally } \\
\text { reasonable }\end{array}$ \\
\hline
\end{tabular}

Adapted from Guyatt $\mathrm{G}$ et al. Grading strength of recommendations and quality of evidence in clinical guidelines. Report from an American College of Chest Physicians task force. Chest 2006; 129:174-181 (62). 


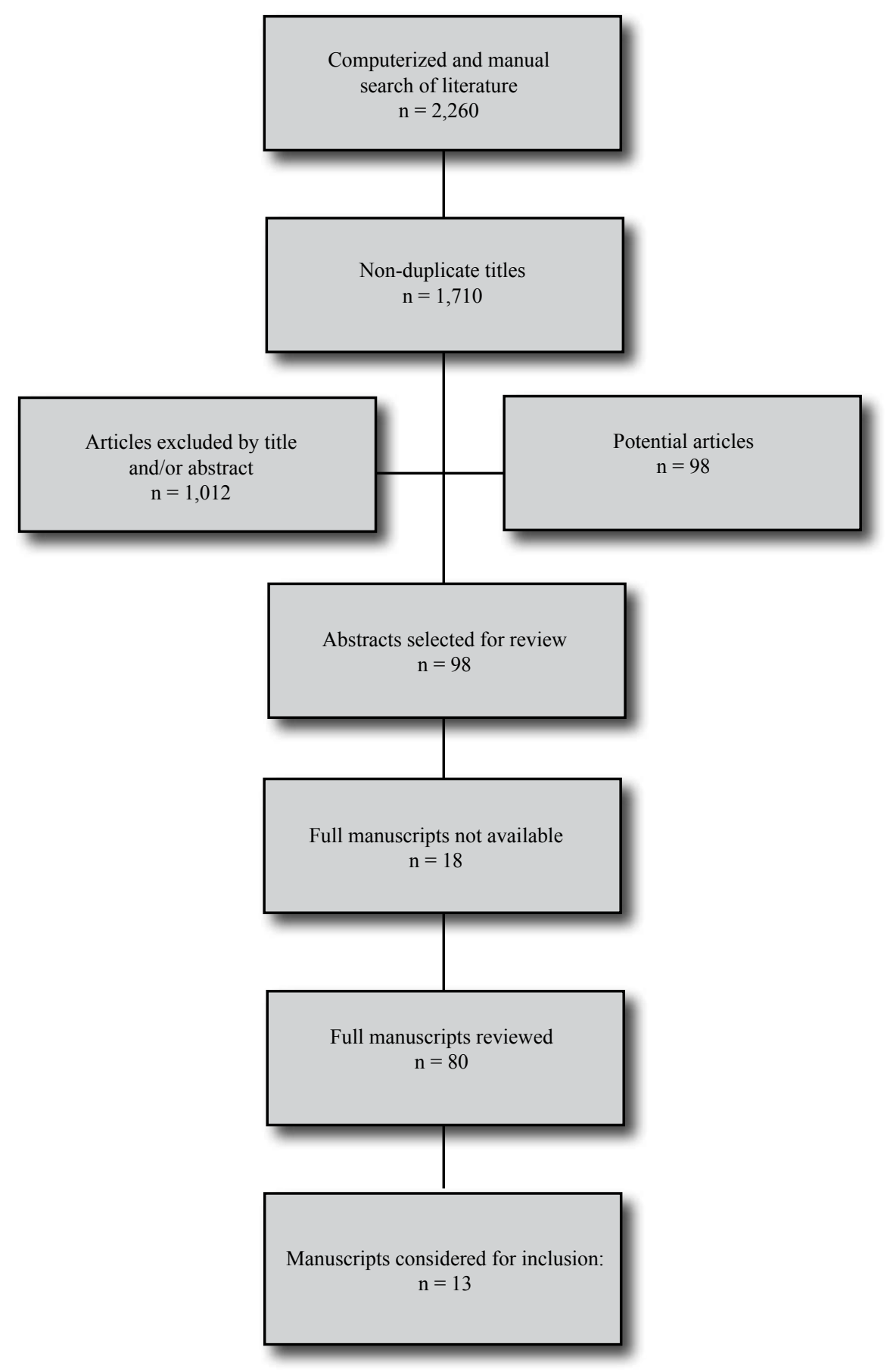

Fig. 1. Literature search flow diagram for sacroiliac joint diagnostic studies. 
to exclude patients with comparative blocks or unresolveable technical flaws (Table 3).

Fortin et al (25) used pain provocation during a single anesthetic block. Schwarzer et al (11) used $\geq$ $75 \%$ reduction in pain following a single injection of local anesthetic in patients with pain experienced below L5/S1. Dreyfuss et al (63) used a single injection of local anesthetic and corticosteroid, noted pain provocation, and required more than $90 \%$ diminution in the mean pain score. Slipman et al (27) used $\geq 80 \%$ reduction in general pain on a vascular autonomic signal (VAS) following a single anesthetic injection in low back pain patients. Laslett et al (64) and Young et al (65) used greater than $80 \%$ relief as their criterion standard following single blocks. Maigne et al (66) and Slipman et al (67) both utilized single diagnostic blocks with $75 \%$ and $80 \%$ pain relief, respectively, in evaluating the sensitivity and specificity of radionuclide bone scanning. Broadhurst and Bond (68) utilized a placebo-controlled injection with $\geq 70 \%$ relief and the reduction of pain provocation. However, this study had multiple issues relating to the technical aspects of the injection and volume of injectate (69). Pang et al (70) also utilized a single block. Maigne and Planchon (12) evaluated sacroiliac joint pain after lumbar fusion with a single block with a criterion standard of $75 \%$ pain relief on a VAS with $35 \%$ positive rate of blocks.

Multiple authors used dual blocks with 2 local anesthetics of different duration of action (4,9,10,71-73). These studies met all inclusion criteria for diagnostic accuracy evaluation and thus underwent methodological quality assessment.

\section{Diagnostic Accuracy Studies}

Five studies were incorporated for methodologic quality assessment of diagnostic accuracy of diagnostic sacroiliac joint injections $(4,9,10,71-73)$.

\section{Methodologic Quality Assessment}

The methodologic quality assessment of the 5 studies meeting inclusion criteria are illustrated in Table 4. Two publications by van der Wurff et al $(72,73)$ were from a single study; consequently, 5 studies were included in the methodologic quality assessment. The series of blocks in these studies were performed under fluoroscopic guidance using lidocaine and bupivacaine, with the response and criterion being at least $50 \%$ pain relief.

\section{Study Characteristics}

Table 5 shows the characteristics of the diagnostic studies evaluating the accuracy and prevalence.

Maigne et al (9) studied 54 patients who had chronic (> 50 days) unilateral low back pain (VAS > 4) with or without radiation to the posterior thigh with associated pain and tenderness over the posterior sacroiliac joint. Dual injections were performed, first with a screening lidocaine injection $(2 \mathrm{~mL})$, then with bupivacaine. Nineteen of 54 patients had $\geq 75 \%$ relief from the screening block and 10 of 19 participants had $\geq 75 \%$ improvement lasting longer than 2 hours from the confirmatory bupivacaine block. Among the 54 subjects, 10 or $18.5 \%$ were considered to have sacroiliac joint pain. The false-positive rate using the total number of screening blocks was determined to be

Table 3. Illustration of studies excluded.

\begin{tabular}{|l|l||}
\hline Study & Reason for Exclusion \\
\hline Fortin et al (25) & Used pain provocation during a single anesthetic block. \\
\hline Schwarzer et al (11) & Used single injection of local anesthetic. \\
\hline Dreyfuss et al (63) & Used a single injection of local anesthetic and corticosteroid. \\
\hline Slipman et al (27) & Single anesthetic injection in low back pain patients was used. \\
\hline Laslett et al (64) & Single blocks were used. \\
\hline Young et al (65) & Single blocks were used. \\
\hline Maigne et al (66) & Utilized single diagnostic blocks. \\
\hline Slipman et al (67) & Utilized single diagnostic blocks. \\
\hline Broadhurst and Bond (68) & This study had multiple issues relating to the technical aspects of the injection and volume of injectate (71). \\
\hline Pang et al (70) & Utilized a single block. \\
\hline Maigne and Planchon (12) & Evaluated with a single block. \\
\hline
\end{tabular}


Sacroiliac Joint Injections

Table 4. Methodological quality assessment and scoring of sacroiliac joint studies.

\begin{tabular}{|c|c|c|c|c|c|c|c|c|}
\hline \multirow[b]{2}{*}{ STUDY } & \multirow[b]{2}{*}{$\begin{array}{c}\text { Study } \\
\text { Population } \\
(15)\end{array}$} & \multirow[b]{2}{*}{$\begin{array}{c}\text { Adequate } \\
\text { Description } \\
\text { of Test } \\
(\mathbf{1 0})\end{array}$} & \multicolumn{2}{|c|}{$\begin{array}{l}\text { Appropriate Reference } \\
\text { Standard (30) }\end{array}$} & \multicolumn{2}{|c|}{$\begin{array}{l}\text { Blinded Comparison of Test } \\
\text { (30) }\end{array}$} & \multirow[b]{2}{*}{$\begin{array}{l}\text { Avoidance } \\
\text { of } \\
\text { Verification } \\
\text { Bias (15) }\end{array}$} & \multirow[b]{2}{*}{$\begin{array}{l}\text { TOTAL } \\
(100)\end{array}$} \\
\hline & & & $\begin{array}{c}\text { Appropriate } \\
\text { reference } \\
\text { standard (gold } \\
\text { standard) used } \\
\text { for comparison } \\
\text { (15) }\end{array}$ & $\begin{array}{c}\text { Reference } \\
\text { standard } \\
\text { reproducible } \\
\text { (15) }\end{array}$ & $\begin{array}{c}\text { Evaluation } \\
\text { of test } \\
\text { without } \\
\text { knowledge } \\
\text { of disease } \\
\text { status, if } \\
\text { possible (15) }\end{array}$ & $\begin{array}{c}\text { Independent, } \\
\text { blind } \\
\text { interpretation } \\
\text { of test and } \\
\text { reference } \\
\text { (15) }\end{array}$ & & \\
\hline $\begin{array}{l}\text { Manchikanti et } \\
\text { al (4) }\end{array}$ & 15 & 10 & 5 & 5 & 5 & 10 & 15 & 65 \\
\hline Maigne et al (9) & 15 & 10 & 5 & 5 & 5 & 10 & 15 & 65 \\
\hline Irwin et al (10) & 15 & 10 & 5 & 5 & 5 & 10 & 15 & 65 \\
\hline Laslett et al (71) & 15 & 10 & 5 & 5 & 5 & 10 & 15 & 65 \\
\hline $\begin{array}{l}\text { van der Wurff et } \\
\text { al (72) }\end{array}$ & 15 & 10 & 5 & 5 & 5 & 10 & 15 & 65 \\
\hline
\end{tabular}

( ) weighted item score

Methodological criteria and scoring adapted from West S et al. Systems to Rate the Strength of Scientific Evidence, Evidence Report, Technology Assessment No. 47. AHRQ Publication No. E016 (43).

$20 \%$ (12). Since only patients with a high likelihood of sacroiliac joint pain were tested, the calculated prevalence rate of $18.5 \%$ may not be reliable. The authors also excluded 3 patients who remained pain-free after receiving the screening block. In addition, 3 others had a temporary sciatic palsy after the first block resulting from leakage of the anesthetic. In 7 cases, penetration of the sacroiliac joint was technically impossible because of degenerative changes. Consequently, among the 67 enrolled patients, only 54 completed the study because the injected contrast was insufficient to fill the entire joint cavity, no arthrographic interpretation was conducted.

Manchikanti et al (4) evaluated 120 patients who presented to a pain clinic with low back pain of $\geq 6$ months. Twenty patients with suspected sacroiliac joint involvement (i.e., negative facet blocks, spontaneous pain in the sacral region, sacroiliac joint tenderness, and positive provocative maneuvers) then underwent screening sacroiliac joint injections with $2 \%$ lidocaine followed in 3 to 4 weeks by confirmatory bupivacaine blocks. Six patients had $\geq 80 \%$ short-acting pain relief following the screening block. Among these subjects, 2 patients experienced concordant pain relief after the confirmatory bupivacaine block. When calculated for all patients with low back pain, the overall prevalence of $\mathrm{SI}$ joint pain was $2 \%$. When patients with radicular symptomatology and facetogenic pain were ruled out, the point prevalence rate increased to $10 \%$ with a false-positive rate of $22 \%$. Despite the otherwise strong methodology, the small sample size limits the applicability and conclusions that can be drawn.

In a retrospective review involving 158 patients, Irwin et al (10) evaluated the prevalence of sacroiliac joint pain in various subgroups using dual comparative local anesthetic blocks. Fluoroscopically guided intraarticular injections were performed first with $2 \mathrm{~mL}$ of $2 \%$ lidocaine, followed by $2 \mathrm{~mL}$ of $0.25 \%$ bupivacaine with corticosteroid for the confirmatory injection. A positive response was defined as greater than $70 \%$ pain relief lasting at least 3 and 4 hours after the first and second injections, respectively. Overall, the percentage of patients diagnosed with sacroiliac joint pain using the dual comparative local anesthetic injections was $26.7 \%$ (42/158). The authors found that patients diagnosed with sacroiliac joint pain tend to be older than those with other pain sources, whereas, gender, age, and smoking status were not correlated with the response to diagnostic blocks. Although this study was the largest and one of the most externally valid among the studies analyzed, its retrospective nature raises multiple issues related to validity. These issues include 
Table 5. Characteristics of reported diagnostic studies evaluating prevalence.

\begin{tabular}{|c|c|c|c|c|}
\hline Study & Participants & Objective(s) & Interventions(s) & Result(s) \\
\hline Maigne et al (9) & $\begin{array}{l}54 \text { patients aged } 18-75 \\
\text { with chronic unilateral } \\
\text { LBP with or without } \\
\text { radiation to the poste- } \\
\text { rior thigh for }>50 \text { days } \\
\text { (median } 4.2 \text { months). } \\
\text { Patients had failed epi- } \\
\text { dural or lumbar facet } \\
\text { injections. }\end{array}$ & $\begin{array}{l}\text { To determine the } \\
\text { prevalence of sacroiliac } \\
\text { joint pain in a selected } \\
\text { population of patients } \\
\text { with low back pain } \\
\text { and assess certain pain } \\
\text { provocation tests. }\end{array}$ & $\begin{array}{l}\text { Successful blockade of the sacroiliac } \\
\text { joint in } 54 \text { patients. A screening block } \\
\text { was done with } 2 \% \text { lidocaine and a con- } \\
\text { firmatory block was performed with } \\
\text { bupivacaine } 0.5 \% \text {. Greater than } 75 \% \\
\text { relief was considered a positive block. }\end{array}$ & $\begin{array}{l}\text { Prevalence }=18.5 \% \\
\text { False-positive rate }=20 \%\end{array}$ \\
\hline $\begin{array}{l}\text { Manchikanti et } \\
\text { al (4) }\end{array}$ & $\begin{array}{l}120 \text { patients (age } 18- \\
90 \text { ) presenting to the } \\
\text { clinic with }>6 \text { months } \\
\text { of low back pain and } \\
\text { no structural basis for } \\
\text { the pain by radiograph- } \\
\text { ic imaging. } 20 \text { patients } \\
\text { were evaluated for SI } \\
\text { joint pain. }\end{array}$ & $\begin{array}{l}\text { To determine the } \\
\text { frequency of various } \\
\text { structures responsible } \\
\text { for low back pain. }\end{array}$ & $\begin{array}{l}\text { All patients had facet blocks. } \\
\text { Non-responders who fit criteria } \\
\text { had double injection sacroiliac joint } \\
\text { blocks. The screening block was done } \\
\text { with } 2 \% \text { lidocaine and the confirma- } \\
\text { tory block was performed using } 0.5 \% \\
\text { bupivacaine. }\end{array}$ & $\begin{array}{l}\text { The incidence of sacroiliac } \\
\text { joint pain was } 2 \% \text { of the } \\
\text { overall sample and } 10 \% \\
\text { of those suspected to have } \\
\text { sacroiliac joint pain. The } \\
\text { false-positive rate was } 22 \% \text {. }\end{array}$ \\
\hline Irwin et al (10) & $\begin{array}{l}158 \text { patients under- } \\
\text { went sacroiliac joint } \\
\text { injections with average } \\
\text { symptoms duration of } \\
34 \text { months. Patients } \\
\text { failed conservative } \\
\text { modalities prior to } \\
\text { injection therapy. }\end{array}$ & $\begin{array}{l}\text { To evaluate prevalence } \\
\text { and correlation be- } \\
\text { tween age, gender, and } \\
\text { body mass index by } \\
\text { dual comparative local } \\
\text { anesthetic blocks. }\end{array}$ & $\begin{array}{l}\text { The fluoroscopically guided contrast- } \\
\text { enhanced sacroiliac joint injections } \\
\text { were performed initially with } 2 \mathrm{~mL} \text { of } \\
2 \% \text { lidocaine for the first injection, fol- } \\
\text { lowed by } 2 \mathrm{~mL} \text { of } 0.25 \% \text { bupivacaine, a } \\
\text { local anesthetic, for the confirmatory } \\
\text { injection. A patient was required to } \\
\text { have at least } 70 \% \text { reduction of familiar } \\
\text { painful symptoms after the initial } \\
\text { injection for } 3 \text { or } 4 \text { hours for positive } \\
\text { response. }\end{array}$ & $\begin{array}{l}26.6 \% \text { were found to have } \\
\text { sacroiliac joint pain by dual } \\
\text { injections. } \\
\text { Estimated false-positive } \\
\text { rate }=53.8 \%\end{array}$ \\
\hline Laslett et al (71) & $\begin{array}{l}48 \text { patients received } \\
\text { initial sacroiliac joint } \\
\text { diagnostic injec- } \\
\text { tion, derived from } 62 \\
\text { patients with buttock } \\
\text { pain with or without } \\
\text { lumbar or lower ex- } \\
\text { tremity symptoms. }\end{array}$ & $\begin{array}{l}\text { To assess the diag- } \\
\text { nostic accuracy of } \\
\text { clinical examination in } \\
\text { identifying symptom- } \\
\text { atic and asymptomatic } \\
\text { sacroiliac joints using } \\
\text { double-diagnostic } \\
\text { injections as reference } \\
\text { standard. }\end{array}$ & $\begin{array}{l}16 \text { patients had positive response to } \\
\text { sacroiliac joint injections and } 5 \text { of } \\
\text { them did not receive a confirmatory } \\
\text { diagnostic injection because they de- } \\
\text { rived such symptomatic relief from the } \\
\text { initial procedure that a confirmatory } \\
\text { injection could not be justified. } \\
11 \text { patients received a confirmatory } \\
\text { injection and all of them tested posi- } \\
\text { tive. Overall } 32 \text { patients had negative } \\
\text { sacroiliac joint injections and did not } \\
\text { require a confirmatory injection. }\end{array}$ & $\begin{array}{l}25.6 \% \text { were found to have } \\
\text { sacroiliac joint pain by dual } \\
\text { injections. } \\
\text { Estimated false-positive } \\
\text { rate = none }\end{array}$ \\
\hline $\begin{array}{l}\text { van der Wurff et } \\
\text { al (72) }\end{array}$ & $\begin{array}{l}\text { Total number of } 140 \\
\text { patients with chronic } \\
\text { low back pain visiting } \\
\text { the pain clinic in the } \\
\text { Netherlands, } 60 \text { pa- } \\
\text { tients entered the study. }\end{array}$ & $\begin{array}{l}\text { To compare the } \\
\text { diagnostic accuracy of } \\
\text { multi-test regimen of } \\
5 \text { sacroiliac joint pain } \\
\text { provocation test with } \\
\text { fluoroscopically con- } \\
\text { trolled double sacro- } \\
\text { iliac joint blocks using } \\
\text { a short- and long-act- } \\
\text { ing local anesthetic. }\end{array}$ & $\begin{array}{l}\text { The fluoroscopically guided contrast } \\
\text { enhanced sacroiliac joint injections } \\
\text { were performed initially with } 2 \mathrm{~mL} \text { of } \\
2 \% \text { lidocaine and next time with } 0.25 \% \\
\text { bupivacaine. } \\
\text { A reduction in the patient's character- } \\
\text { istic pain of } 50 \% \text { or more on the VAS } \\
\text { remaining for at least one hour for } \\
\text { lidocaine or } 4 \text { hours for bupivacaine } \\
\text { was considered as positive. When a } \\
\text { patient showed a VAS reduction after } \\
\text { both intraarticular sacroiliac joint } \\
\text { blocks, this was considered a positive } \\
\text { response. Any other outcome was } \\
\text { considered a negative response. }\end{array}$ & $\begin{array}{l}\text { Prevalence }=38 \% \\
\text { False-positive rate }=21 \%\end{array}$ \\
\hline
\end{tabular}


non-uniform screening procedures, and lack of standardization regarding injection technique. The higher false-positive rate reported in this study (53.8\%) can be attributed to using the number of positive screening blocks as the denominator, rather than the initial number of injections

van der Wurff et al (72) evaluated 60 patients meeting the inclusion criteria of pain below L5 overlying the posterior aspect of sacroiliac joint and pain intensity exceeding 50 on a $0-100$ VAS scale. Excluded patients included those with ankylosing spondylitis, leg-length discrepancies greater than $2 \mathrm{~cm}$, positive Waddell's signs, clinical osteoarthritis, and radicular pain with focal neurological signs or symptoms. Each patient underwent 2 diagnostic sacroiliac joint injections on separate occasions with short and long-acting local anesthetics. All blocks were performed by an anesthesiologist unaware of the results of provocation testing by an independent investigator who examined the patient prior to the procedure. A positive response was pre-designated as $\geq 50 \%$ pain relief lasting for at least one hour after the intraarticular lidocaine injection and at least 4 hours after the bupivacaine block. Any other outcome was considered to be a negative response. Twenty-seven patients $(45 \%)$ responded positively to both blocks. Among those patients with 3 or more positive provocative tests, 29 achieved a positive response following the initial block, with 23 obtaining prolonged pain relief after the bupivacaine injection (true-positives). One patient did not respond to either block.

Laslett et al (71) evaluated 48 patients who underwent screening diagnostic sacroiliac joint injections from amongst a sample of 62 with buttock pain with or without lumbar or lower extremity symptoms. Sixteen patients had a positive response, predetermined to be $\geq 80 \%$ relief. Five responders obtained long-term relief, leaving 11 patients who underwent confirmatory blocks with bupivacaine. All confirmatory blocks were positive. Ten of the 11 sacroiliac joint patients met clinical examination criteria for having sacroiliac joint pain, defined as 3 (of 5) positive provocation tests in absence of peripheralization or centralization. Potential sources of bias were that these patients were specifically selected for injection therapy and exposed to multiple procedures. Excluding the 5 patients with a prolonged response to the lidocaine screening blocks, the prevalence rate in this pre-selected was $26 \%$ (Table 6). Potential confounding factors include the lack of false-positive responses and that some of these patients were included in other studies and publications $(64,65,71)$.

\section{Level of Evidence}

The indicated level of evidence is Level II-2, as illustrated in Table 1.

\section{Provocation Testing}

There is no universally accepted gold standard for the diagnosis of low back pain originating from the sacroiliac joint. The recommended reference standard involves either anesthetic or provocative injections; however, doubts have been cast on the validity of a sacroiliac joint block as a diagnostic gold standard. A review by Berthelot et al (74) concluded clinical signs and maneuvers to be unreliable for diagnosing pain originating within the sacroiliac joint, being fraught with both low sensitivity and specificity. But this review also concluded that sacroiliac joint blocks were similarly unreliable, since pain patterns formerly attributed to the sacroiliac joint can be related to extraarticular structures, most notably the numerous ligaments surrounding the joint.

Table 6. Data of prevalence of sacroiliac joint pain by controlled diagnostic blocks.

\begin{tabular}{|l|c|c|c|c|}
\hline \multicolumn{1}{|c|}{ Study } & $\begin{array}{c}\text { Methodologic } \\
\text { Criteria }\end{array}$ & \# of Subjects & Prevalence Estimates & False-Positive Rate \\
\hline Manchikanti et al (4) & 65 & 20 & $10 \%(95 \% \mathrm{CI}, 0 \%-23 \%)$ & $22 \%(95 \% \mathrm{CI}, 3 \%-42 \%)$ \\
\hline Maigne et al (9) & 65 & 54 & $18.5 \%(95 \% \mathrm{CI}, 8 \%-29 \%))$ & $20 \%(95 \% \mathrm{CI}, 8 \%-33 \%)$ \\
\hline Irwin et al (10) & 65 & 158 & $26.6 \%(95 \% \mathrm{CI}, 20 \%-34 \%)$ & $53.8 \%(95 \% \mathrm{CI}, 43 \%-64 \%)$ \\
\hline Laslett et al (71) & 65 & $43 / 48$ & $25.6 \%(95 \% \mathrm{CI}, 12 \%-39 \%)$ & $0 \%$ \\
\hline van der Wurff et al (72) & 65 & 60 & $38 \%(95 \% \mathrm{CI}, 26 \%-51 \%)$ & $21 \%(95 \% \mathrm{CI}, 7 \%-35 \%)$ \\
\hline
\end{tabular}

$\mathrm{CI}=$ confidence interval 
In contrast, Szadek et al (36) and Hancock et al (28) in 2 separate systematic reviews showed a positive correlation between provocation testing and diagnostic blocks. Hancock et al (28) included 6 studies in their analysis $(63,64,66,67,68,71,72)$ while Szadek et al included 15 (36). In a systematic appraisal of the literature assessing the accuracy of multiple tests for back pain utilizing QUADAS criteria, Simpson and Gemmell (75) identified 5 studies that focused on sacroiliac joint pain $(63,64,68,71,76)$. They found no single test to be consistently valid.

Among the studies analyzed in these reviews, 3 employed dual blocks $(9,71,72)$, and hence were considered.

Maigne et al (9) determined the prevalence of sacroiliac joint pain in a selected population of patients suffering from low back pain and assessed the validity of various pain provocation tests. The patients underwent 7 sacroiliac pain provocation tests, which included the distraction test, compression test, sacral pressure test, Gaenslen's test, Patrick's test, resisted external rotation of the hip, and direct pressure on the pubic symphysis, before and after a screening block. However, no statistically significant association was found between the response to the blocks and any single clinical parameter. They concluded that no pain provocation test was a useful predictor of sacroiliac joint pain.

Laslett et al (71) concluded that the diagnostic accuracy of the clinical examination in conjunction with reasoning processes was superior to sacroiliac joint pain provocation maneuvers as stand alone tests. Excluding patients whose pain centralized or peripheralized increased the positive likelihood ratio for identifying a symptomatic sacroiliac joint(s) in patients with 3 or more provocative tests.

van der Wurff et al (72) evaluated the diagnostic accuracy of a multi-test regimen of 5 sacroiliac joint pain provocation tests by comparing it to the results of fluoroscopically guided double local anesthetic blocks. The five provocation tests included the distraction test, compression test, thigh thrust, Patrick's sign, and Gaenslen's test. Among the 60 patients studied, $45 \%$ obtained a positive response to both blocks. Whereas none of the provocation tools were specific as a stand-alone test, a combination of 3 or more positive tests was deemed to be a reliable indicator. Seven patients were categorized as having false-positive blocks. Four of the 23 double-block patients obtained complete relief of their pain after injection such that
19 patients could be considered "true-positives." The false-positive rate for this study was estimated to be $21 \%$ with a prevalence rate of $38 \%$. The authors' conclusion that a correlation exists between the finding of 3 or more positive pain provocation tests and an analgesic response to double intraarticular sacroiliac joint blocks corroborates the results of Laslett et al (71). This study is limited by a pain relief criterion standard response of $\geq 50 \%$ rather than $\geq 80 \%$ pain relief after injection.

\section{Level of Evidence}

The indicated evidence for the accuracy of provocative maneuvers in diagnosis of sacroiliac joint injections pain is limited or Level II-3.

\section{Accuracy of Imaging and Clinical History}

The value of medical history, physical examination, and radiological imaging has been questioned in the diagnosis of sacroiliac joint pain. In a prospective study evaluating the diagnostic utility of a battery of accepted sacroiliac joint tests recommended by a multidisciplinary expert panel, Dreyfuss et al (63) attempted to discern whether a single test or an ensemble of investigative maneuvers were sufficiently useful in identifying a painful sacroiliac joint. They concluded that sacroiliac joint pain is resistant to identification by history and physical examination data. Although distinct pain patterns have been previously described by an assortment of investigators $(11,25,27)$, similar referral maps may be produced by other structures. Schwarzer et al (11) found radiation to the groin to be the only descriptive quality reliably associated with pain relief after a single sacroiliac joint block.

Noting that history and physical examination findings associated with somatically referred pain can be unreliable and non-specific, Jung et al (77) evaluated the accuracy of "pain distribution pattern templates" in predicting pain relief following confirmatory intraarticular and deep interosseous ligament blocks. They concluded that $46 \%$ of patients with sacroiliac joint arthropathy could be diagnosed based on pain distribution patterns.

Neither has radiological imaging been found to be an accurate indicator of a painful sacroiliac joint. Puhakka et al $(78,79)$ performed 2 evaluations, one with magnetic resonance imaging (MRI) of the normal sacroiliac joint with correlation to histology and the second one with MRI abnormalities of the sacroiliac 
joints in early spondyloarthropathy with a one-year follow-up study. They concluded that coronal MRI does not allow assessment of normal anatomy. But when there are variants or abnormalities of the ventral and dorsal margins of the cartilaginous sacroiliac joint and in early spondyloarthropathy, MRI can detect significant inflammatory and destructive changes of the sacroiliac joints over a one-year follow-up, in spite of minimal changes in the clinical parameters. However, the MRI changes and inflammatory activity are not detectable by CT and x-ray examinations. Thus, MRI may be a sensitive method, without risks, for early diagnosis and for following disease progression in spondyloarthropathy. Radiologic studies can assist in determining anatomical integrity (80). A retrospective study (81) showed that CT scans were negative in $42 \%$ of symptomatic sacroiliac joints.

Song et al (37) evaluated the diagnostic value of scintography in detecting sacroiliitis in ankylosing spondylitis and those with probable sacroiliitis without x-ray changes. Following an extensive literature search, they concluded that scintography of the sacroiliac joints is at most of limited diagnostic value.

\section{Therapeutic Sacroiliac Joint Interventions}

The literature search yielded 33 relevant evaluations for intraarticular injections and radiofrequency neurotomy (Fig. 2).

Among the many studies considered for inclusion (82-109), there were 5 randomized trials $(83,84,86,91,107)$, with the remainder consisting of retrospective reviews and observational reports $(82,85,87-91,93-106,108,109)$.

\section{Intraarticular Sacroiliac Joint Injections}

Based on the search, 17 publications were selected (82-98). Of these, 4 studies were randomized trials $(83,84,86,91)$ and 14 were observational reports $(82,85,87-90,92-99)$.

Among the 4 randomized trials meeting criteria for initial evaluation $(83,84,86,91)$, all were excluded due to lack of a valid diagnosis prior to therapeutic interventions. These studies also had other methodological issues such as lack of long-term follow-up (83), using children as the target population (86), and evaluating periarticular injections done for spondyloarthropathy (91).

Among the 14 observational reports $(82,85,87$ $90,92-99)$, none met inclusion criteria. The basis for exclusion included lack of controlled diagnostic blocks to establish diagnosis of sacroiliac joint pain, evaluating only patients with spondyloarthropathy $(86,87,89,90)$, and not following patients for 6 months. Thus, no methodologic quality assessment was performed for the category of intraarticular injections.

\section{Radiofrequency Neurotomy}

The literature search yielded 9 relevant reports available for review (100-108). Of these, one was randomized (107) and the rest were observational.

\section{Methodologic Quality Assessment}

The study by Cohen et al (107) was double blind placebo-controlled; however, it utilized a single diagnostic block as the means for diagnosis. Another study (103) had inconsistent descriptions utilizing interligamentous rather than intraarticular injections. Ferrante et al (100), Gevargez et al (101), and Buijs et al (104) all utilized single diagnostic blocks. Kapural et al (108) had only short-term follow-up of 3 to 4 months, even though they utilized dual blocks.

Burnham and Yasui (105), Cohen and Abdi (102), and Vallejo et al (106) utilized dual blocks.

Methodologic quality assessment is illustrated in Table 7.

\section{Characteristics of Included Studies}

Vallejo et al (106) tested the hypothesis that pulsed radiofrequency of the posterior rami from L4 to S3 would provide therapeutic benefit to patients with intractable sacroiliac joint dysfunction. One hundred and twenty-six patients with suspected sacroiliac joint pain were examined for this study. Dual diagnostic blocks with local anesthetic and corticosteroid using $\geq 75 \%$ relief as the success criterion were done to minimize false-positive results and confirm the pain generator. This resulted in 52 patients with confirmed disease. Thirty of these patients obtained $\geq 50 \%$ relief lasting longer than 12 weeks. The remaining 22 subjects were offered the treatment. The follow-up period was 6 months and outcome measures included VAS scoring and a quality of life assessment tool. Sixteen of the 22 were found to have good ( $\geq 50 \%$ ) to excellent $(\geq 80 \%$ ) results; however, in only 7 patients did this improvement exceed 17 weeks. There was no annotation about how many patients obtained 6 or greater months of relief. This study is limited by its observational nature, and the small number of patients. In addition, only 7 of 22 patients experienced between 17 and 32 weeks worth of relief, which is similar to 


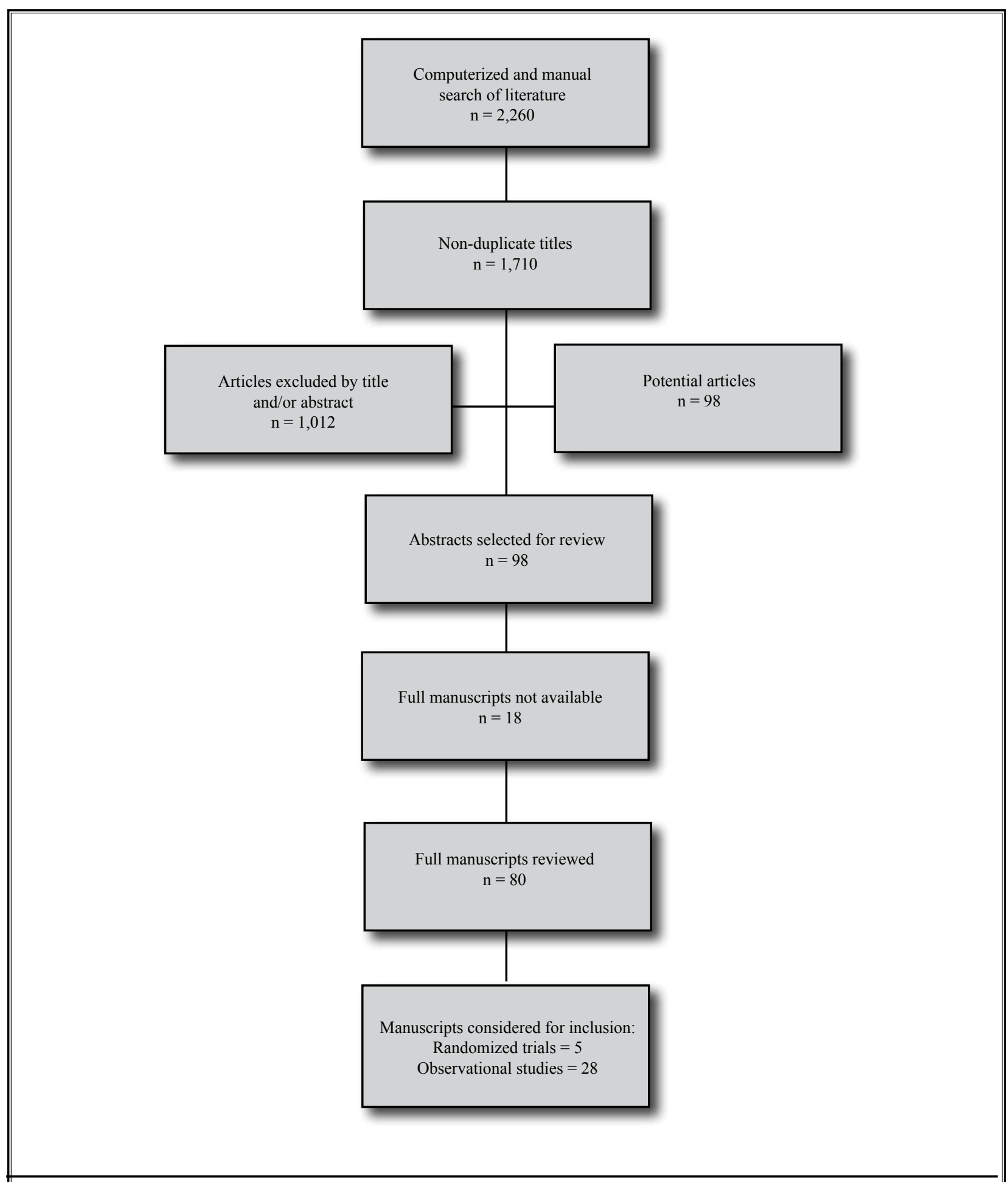

Fig. 2. The flow diagram illustrating therapeutic studies evaluating sacroiliac joint interventions. 
Table 7. Methodologic quality assessment criteria for radiofrequency neurotomy of sacroiliac joint.

\begin{tabular}{|c|c|c|c|c|}
\hline & $\begin{array}{c}\text { Weighted } \\
\text { Score } \\
\text { (points) }\end{array}$ & $\begin{array}{l}\text { Vallejo et } \\
\text { al (106) }\end{array}$ & $\begin{array}{c}\text { Cohen } \\
\text { \& Abdi } \\
\text { (102) }\end{array}$ & $\begin{array}{l}\text { Burnham \& } \\
\text { Yasui (105) }\end{array}$ \\
\hline 1. Study Question & 2 & 2 & 2 & 2 \\
\hline - Clearly focused and appropriate question & & 2 & 2 & 2 \\
\hline 2. Study Population & 8 & 5 & 5 & 5 \\
\hline - Description of study population & 5 & 5 & 5 & 5 \\
\hline - Sample size justification & 3 & 0 & - & - \\
\hline 3. Comparability of Subjects & 22 & 5 & 5 & 5 \\
\hline - Specific inclusion/exclusion criteria for all groups & 5 & 5 & 5 & 5 \\
\hline - Criteria applied equally to all groups & 3 & - & - & - \\
\hline $\begin{array}{l}\text { - Comparability of groups at baseline with regard to disease status and prog- } \\
\text { nostic factors }\end{array}$ & 3 & - & - & - \\
\hline $\begin{array}{l}\text { - Study groups comparable to non-participants with regard to confounding } \\
\text { factors }\end{array}$ & 3 & - & - & - \\
\hline - Use of concurrent controls & 5 & - & - & - \\
\hline - Comparability of follow-up among groups at each assessment & 3 & - & - & - \\
\hline 4. Exposure or Intervention & 11 & 8 & 8 & 8 \\
\hline - Clear definition of exposure & 5 & 5 & 5 & 5 \\
\hline - Measurement method standard, valid and reliable & 3 & 3 & 3 & 3 \\
\hline - Exposure measured equally in all study groups & 3 & - & - & - \\
\hline 5. Outcome measures & 20 & 13 & 14 & 15 \\
\hline - Primary/secondary outcomes clearly defined & 5 & 5 & 5 & 5 \\
\hline - Outcomes assessed blind to exposure or intervention & 5 & - & - & - \\
\hline - Method of outcome assessment standard, valid and reliable & 5 & 5 & 5 & 5 \\
\hline - Length of follow-up adequate for question & 5 & 3 & 4 & 5 \\
\hline 6. Statistical Analysis & 19 & 8 & 8 & 8 \\
\hline - Statistical tests appropriate & 5 & 5 & 5 & 5 \\
\hline - Multiple comparisons taken into consideration & 3 & 3 & 3 & 3 \\
\hline - Modeling and multivariate techniques appropriate & 2 & - & - & - \\
\hline - Power calculation provided & 2 & - & - & - \\
\hline - Assessment of confounding & 5 & - & - & - \\
\hline - Dose-response assessment if appropriate & 2 & - & - & - \\
\hline 7. Results & 8 & 5 & 5 & 6 \\
\hline - Measure of effect for outcomes and appropriate measure of precision & 5 & 3 & 3 & 3 \\
\hline - Adequacy of follow-up for each study group & 3 & 2 & 2 & 3 \\
\hline 8. Discussion & 5 & 5 & 5 & 5 \\
\hline $\begin{array}{l}\text { - Conclusions supported by results with possible biases and limitations taken } \\
\text { into consideration }\end{array}$ & & 5 & 5 & 5 \\
\hline 9. Funding or Sponsorship & 5 & 5 & 5 & 5 \\
\hline - Type and sources of support for study & & 5 & 5 & 5 \\
\hline TOTAL SCORE & 100 & 56 & 57 & 59 \\
\hline
\end{tabular}

Adapted and modified from West S et al. Systems to Rate the Strength of Scientific Evidence, Evidence Report, Technology Assessment No. 47. AHRQ Publication No. 02-E016 (43). 
the duration of benefit obtained from local anesthetic blocks with or without steroids (110-116).

Burnham and Yasui (105) published the results of a pilot study evaluating bipolar radiofrequency neurotomy. They evaluated 9 subjects with sacroiliac joint pain confirmed by local anesthetic joint and lateral branch nerve blocks. These subjects were treated with a series of radiofrequency strip lesions performed adjacent to the lateral dorsal foraminal aperture plus conventional monopolar lesioning at the L5 dorsal ramus. Follow-up visits were conducted at one, 3, 6, 9, and 12 months after the procedure. Significant reductions in back and leg pain frequency and severity, and analgesic intake were demonstrated at all points. Complications were minimal. Overall, 8 of the 9 subjects were satisfied with the procedure. The median improvement in pain intensity was 4.1 on a $0-10$ numeric rating scale and the reduction in disability was 17.8 on the Oswestry Disability Index (ODI). Overall satisfaction was $67 \%$ at 12 month follow-up. Limitations include the small number of patients $(n=9)$ recruited from one practice.

Cohen and Abdi (102) performed radiofrequency lesioning on 9 patients who experienced greater than $80 \%$ pain relief following intraarticular joint injection(s) and greater than 50\% relief following L4-5 primary dorsal rami and S1-3 lateral branches blocks. Eight of 9 patients ( $89 \%$ ) obtained $50 \%$ or greater pain relief from this procedure that persisted at their 9-month follow-up. The authors concluded that in patients with injection confirmed sacroiliac joint pain who respond to L4-L5 dorsal rami and S1-3 lateral branch blocks, radiofrequency denervation can be an effective treatment. Limitations of this study include the observational nature and small number of patients.

\section{Characteristics of Excluded Studies}

Among the studies failing to meet the strict criteria for this evaluation was a randomized, placebocontrolled study evaluating lateral branch radiofrequency denervation by Cohen et al (107). Except for dual blocks, the study meets all the criteria for randomized trials (117) and the reporting guidelines of CONSORT (118). This study was also the first to utilize cooled probe radiofrequency technology, which can increase the lesion size by a factor of 8 (31). The authors randomized 28 patients from amongst 90 potential candidates with predominantly axial low back pain to receive either cooled radiofrequency denervation from L4-S3 or sham lesioning. The main inclusion criterion was $>75 \%$ pain relief lasting at least 3 hours following a single intraarticular block performed with a $3 \mathrm{~mL}$ solution containing $2 \mathrm{~mL}$ of bupivacaine and $40 \mathrm{mg}$ of depomethylprednisolone. Those patient's allocated to the placebo group who failed to obtain significant benefit were eligible to crossover to an open-label parallel group that received conventional radiofrequency denervation, 3 and 6 months after the procedure, 64\% $(n=9)$ patients and $57 \%(n=8)$ patients undergoing cooled radiofrequency lesioning experienced $>50 \%$ pain relief accompanied by significant functional improvement. In contrast, none of the sham-treated patients experienced significant improvement 3 months after the procedure. In the crossover treatment group $(n=11), 6(55 \%)$ and $4(36 \%)$ patients experienced a positive outcome 3 and 6 months post-procedure. However, one year after treatment, only 2 patients $(14 \%)$ in the treatment group continued to demonstrate persistent pain relief. The authors concluded that these results furnished preliminary evidence that L4 and L5 primary dorsal rami and S1 to S3 lateral branch radiofrequency denervation may provide intermediate-term pain relief and functional benefit in well-selected patients with suspected sacroiliac joint pain. They also conceded that larger studies were needed to confirm these results and identify the optimal candidates and treatment parameters for this therapy.

This study provides strong evidence that response to radiofrequency denervation is superior to placebo. The limitations of the study include the small number of patients, the failure to exclude false-positive responders with a single uncontrolled sacroiliac joint block, the utilization of different types of radiofrequency technology, and the abridged outcome measures after 6 months.

\section{Level of Evidence}

Based on the available literature, evidence is unavailable for intraarticular sacroiliac joint injections for therapeutic purposes. For radiofrequency neurotomy, the indicated evidence is Level II-3 (limited). The recommendations based on Guyatt et al's (62) criteria are 2B/a weak recommendation for radiofrequency neurotomy for sacroiliac joint pain. 


\section{Discussion}

Based on this systematic review that included 5 studies evaluating the diagnostic accuracy of sacroiliac joint injections, the indicated evidence is Level II-2. For therapeutic interventions, there was no evidence supporting or refuting intraarticular injections. For radiofrequency neurotomy, the indicated evidence is Level II-3 or limited. The prevalence of sacroiliac joint pain is estimated to range between $10 \%$ and $38 \%$, with the false-positive rate range between $20 \%$ and $54 \%$ for uncontrolled single blocks $(4,9,10,71,72)$. This evaluation also determined that a combination of non-invasive provocative measures have limited ability to discriminate between sacroiliac joint pain and other lumbar spine disorders (level of evidence II-3). The results of this systematic review are similar to those from previous systematic reviews $(1,2)$.

The inclusion criteria formulated for this review considered only those studies in which a double-diagnostic block paradigm was used to establish a painful sacroiliac joint. This was done for several reasons. First it was felt that using true placebo blocks for diagnostic purposes are generally considered to be unethical and impractical. Yet, without the use of double comparative blocks, one cannot reliably eliminate false-positive responders. The use of double-blocks to select patients for lumbar facet joint interventions is far more consistent than for SI joint therapies $(4,31,44,48-50,119-124)$. Further confounding the use of double-blocks in selecting candidates for sacroiliac joint denervation are the uncertainties and vagaries surrounding the nerve supply (125). This has led some investigators to suggest that double sacroiliac joint injections are the most reliable means to select treatment candidates. Despite our advocacy for double-diagnostic selection criteria, the disparities in published studies indicate that this is not a universally accepted criterion. Furthermore, what little literature does exist on this topic suggests that using double blocks prior to radiofrequency denervation may not improve treatment outcomes (126).

A second controversial issue surrounds whether or not intraarticular injections are more advantageous than peri-articular injections. The ligamentous connections surrounding the SI joint are intricate and complex. Patients may exhibit either intra- or extraarticular SI pathology, but no reliable means exists to distinguish between the two. For therapeutic procedures, both randomized, controlled studies examining peri-articular corticosteroid injections in patients with and without spondyloarthropathy demonstrated significant short-term benefit $(83,91)$. Some patients may even present with both intra- and extraarticular pain generators. A retrospective review by Borowsky and Fagen (98) conducted in 120 patients found the combination of intra- and peri-articular injectate deposition provided superior analgesia than intraarticular injection alone.

The question of whether or not to screen patients for SI joint denervation using intra- or peri-articular injections is no less complicated. In fact, evidence may even support using peri-articular injections to select patients for lateral branch radiofrequency lesioning. In a study by Dreyfuss et al (127) conducted in asymptomatic volunteers, the authors found that multidepth lateral branch injections blocked nociceptive input secondary to ligamentous probing (i.e., extraarticular stimulation) $70 \%$ of the time, compared to only $20 \%$ of the time during capsular distension (i.e., intraarticular stimulation). In the only clinical study that screened patients with extraarticular ligamentous injections, Yin et al (103) reported a $64 \%$ success rate 6-months after sacroiliac joint radiofrequency denervation.

Notwithstanding the contentious issues, based on the current level of evidence, the use of sacroiliac joint injections for diagnostic utilization is moderately supported. Similar to diagnostic utilization, the use of radiofrequency neurotomy remains in constant flux. However, considering that there is no other viable alternative to managing sacroiliac joint pain in patients refractory to corticosteroid injections, the judicious use of this technology in carefully selected patients appears warranted. But it is equally clear that further studies are needed to both refine the selection criteria and improve the technology.

The limitations of this systematic review include the scant literature available for analysis, the flawed methodology utilized in multiple evaluations, and the large scale discrepancies in techniques, outcome measures, and follow-up periods.

In summary, sacroiliac joint injections are safe and reasonable tools when used diagnostically, but therapeutic measures should be cautiously utilized based on strict selection criteria, in parallel with the physician's experience and technical abilities.

\section{Conclusion}

This systematic review lends moderate support for the use of diagnostic sacroiliac joint interven- 
tions in chronic low back and/or lower extremity pain, whereas it provides limited evidence for radiofrequency neurotomy of sacroiliac joint nerve supply. Thus, a cautious approach must be utilized for diagnosis and even more cautious for therapeutic management, either with intraarticular injections or radiofrequency neurotomy based on individual patient circumstances and the clinician's experience and technical capabilities.

\section{Acknowledgments}

The authors wish to thank the editorial board of Pain Physician, for review and criticism in improving the manuscript; Vidyasagar Pampati, MSc, statistician; Sekar Edem for assistance in search of literature; and Tonie M. Hatton and Diane E. Neihoff, transcriptionists (Pain Management Center of Paducah), for their assistance in preparation of this manuscript.

\section{References}

1. Hansen HC, McKenzie-Brown AM, Cohen SP, Swicegood JR, Colson JD, Manchikanti L. Sacroiliac joint interventions: A systematic review. Pain Physician 2007; 10:165-184.

2. McKenzie-Brown A, Shah RV, Sehgal N, Everett CR. A systematic review of sacroiliac joint interventions. Pain Physician 2005; 8:115-125.

3. Boswell MV, Trescot AM, Datta S, Schultz DM, Hansen HC, Abdi S, Sehgal N, Shah RV, Singh V, Benyamin RM, Patel VB, Buenaventura RM, Colson JD, Cordner HJ, Epter RS, Jasper JF, Dunbar EE, Atluri SL, Bowman RC, Deer TR, Swicegood JR, Staats PS, Smith HS, Burton AW, Kloth DS, Giordano J, Manchikanti L. Interventional techniques: Evidencebased practice guidelines in the management of chronic spinal pain. Pain Physician 2007; 10:7-111.

4. Manchikanti L, Singh V, Pampati V, Damron K, Barnhill R, Beyer C, Cash K. Evaluation of the relative contributions of various structures in chronic low back pain. Pain Physician 2001; 4:308-316.

5. Cohen SP. Sacroiliac joint pain: A comprehensive review of anatomy, diagnosis and treatment. Anesth Analg 2005; 101:1440-1453.

6. Foley BS, Buschbacher RM. Sacroiliac joint pain: Anatomy, biomechanics, diagnosis, and treatment. Am J Phys Med Rehabil 2006; 85:997-1006.

7. Forst SL, Wheeler MT, Fortin JD, Vilensky JA. The sacroiliac joint: Anatomy, physiology, and clinical significance. Pain Physician 2006; 9:61-67.

8. Zelle BA, Gruen GS, Brown S, George S. Sacroiliac joint dysfunction: Evaluation and management. Clin J Pain 2005; 21:446-455.

9. Maigne JY, Aivakiklis A, Pfefer F. Results of sacroiliac joint double block and value of sacroiliac pain provocation test in
54 patients with low back pain. Spine 1996; 21:1889-1892.

10. Irwin RW, Watson T, Minick RP, Ambrosius WT. Age, body mass index, and gender differences in sacroiliac joint pathology. Am J Phys Med Rehabil 2007; 86:37-44.

11. Schwarzer AC, Aprill CN, Bogduk M. The sacroiliac joint in chronic low back pain. Spine 1995; 20:31-37.

12. Maigne JY, Planchon CA. Sacroiliac joint pain after fusion. A study with anesthetic blocks. Eur Spine J 2005; 14:654-658.

13. Merskey $H$, Bogduk N. Sacroiliac joint pain in Group XXVII: Sacral spinal or radicular pain syndromes. In Classification of Chronic Pain: Descriptions of Chronic Pain Syndromes and Definition of Pain Terms, 2nd ed. Task Force on Taxonomy of the International Association for the Study of Pain. IASP Press, Seattle, 1994, pp 190-191.

14. Bogduk N. The sacroiliac joint. In Clinical Anatomy of Lumbar Spine and Sacrum, 4th edition. Churchill Livingstone, New York, 2005 pp 173-181.

15. Murata $Y$, Takahashi $K$, Yamagata $M$, Takahashi Y, Shimada Y, Moriya H. Origin and pathway of sensory nerve fibers to the ventral and dorsal sides of the sacroiliac joint in rats. J Orthop Res 2001; 19:379-383.

16. Fortin JD, Kissling RO, O'Connor BL, Vilensky JA. Sacroiliac joint innervation and pain. Am J Orthop 1999; 28:687690.

17. Grob KR, Neuhuber WL, Kissling RO. Innervation of the sacroiliac joint of the human. $Z$ Rheumatol 1995; 54:117-122.

18. Ikeda R. Innervation of the sacroiliac joint. Macroscopical and histological studies. Nippon Ika Daigaku Zasshi 1991; 58:587-596.

19. Vilensky JA, O'Connor BL, Fortin JD, Merkel GJ, Jimenez AM, Scofield BA,
Kleiner JB. Histologic analysis of neural elements in the human sacroiliac joint. Spine 2002; 27:1202-1207.

20. Sakamoto N, Yamashita T, Takebayashi T, Sekine M, Ishii S. An electrophysiologic study of mechanoreceptors in the sacroiliac joint and adjacent tissues. Spine 2001; 26:E468-E471.

21. Solonen KA. The sacroiliac joint in the light of anatomical, roentgenological and clinical studies. Acta Orthop Scand 1957; 27:1-27.

22. Minaki $Y$, Yamashita $T$, Ishii S. An electrophysiological study on the mechanoreceptors in the lumbar spine and adjacent tissues. Neurol Orthop 1996; 20:23-35.

23. Manchikanti L, Boswell MV, Singh V, Hansen HC. Sacroiliac joint pain: Should physicians be blocking lateral branches, medial branches, dorsal rami, or ventral rami? (Letter to the Editor) Reg Anesth Pain Med 2003; 28:490-491.

24. Szadek KM, Hoogland PV, Zuurmond WW, de Lange JJ, Perez RS. Nociceptive nerve fibers in the sacroiliac joint in humans. Reg Anesth Pain Med 2008; 33:36-43.

25. Fortin JD, Dwyer AP, West S, Pier J. Sacroiliac joint: Pain referral maps upon applying a new injection/arthrography technique. Part I: Asymptomatic volunteers. Spine 1994; 19:1475-1482.

26. Fortin JD, Aprill CN, Ponthieux B, Pier J. Sacroiliac joints: Pain referral maps upon applying a new injection/arthrography technique. Part II: Clinical evaluation. Spine 1994; 19:1483-1489.

27. Slipman CW, Jackson HB, Lipetz JS, Chan KT, Lenrow D, Vresilovic EJ. Sacroiliac joint pain referral zones. Arch Phys Med Rehabil 2000; 81:334-338.

28. Hancock MJ, Maher CG, Latimer J, Spindler MF, McAuley JH, Laslett M, Bogduk $\mathrm{N}$. Systematic review of tests to identify 
the disc, SIJ or facet joint as the source of low back pain. Eur Spine J 2007; 16:1539-1550.

29. Buenaventura RM, Shah RV, Patel V, Benyamin R, Singh V. Systematic review of discography as a diagnostic test for spinal pain: An update. Pain Physician 2007; 10:147-164.

30. Datta S, Everett CR, Trescot AM, Schultz DM, Adlaka R, Abdi S, Atluri SL, Smith HS, Shah RV. An updated systematic review of diagnostic utility of selective nerve root blocks. Pain Physician 2007; 10:113-128.

31. Sehgal N, Dunbar EE, Shah RV, Colson JD. Systematic review of diagnostic utility of facet (zygapophysial) joint injections in chronic spinal pain: An update. Pain Physician 2007; 10:213-228.

32. Wolfer L, Derby R, Lee JE, Lee SH. Systematic review of lumbar provocation discography in asymptomatic subjects with a meta-analysis of false-positive rates. Pain Physician 2008; 11:513538.

33. Manchikanti L, Singh V, Derby R, Schultz DM, Benyamin RM, Prager JP, Hirsch JA. Reassessment of evidence synthesis of occupational medicine practice guidelines for interventional pain management. Pain Physician 2008; 11:393482.

34. Saal JS. General principles of diagnostic testing as related to painful lumbar spine disorders. Spine 2002; 27:25382545.

35. Hildebrandt J. Relevance of nerve blocks in treating and diagnosing low back pain - is the quality decisive? Schmerz 2001; 15:474-483.

36. Szadek KM, van der Wurff $P$, van Tulder MW, Zuurmond WW, Perez RR. Diagnostic validity of criteria for sacroiliac joint pain: A systematic review. J Pain 2008; [Epub ahead of print]

37. Song IH, Carrasco-Fernández J, Rudwaleit M, Sieper J. The diagnostic value of scintigraphy in assessing sacroiliitis in ankylosing spondylitis: A systematic literature research. Ann Rheum Dis 2008; 67:1535-1540.

38. Rubinstein SM, van Tulder M. A best-evidence review of diagnostic procedures for neck and low-back pain. Best Pract Res Clin Rheumatol 2008; 22:471-482.

39. Airaksinen O, Brox Jl, Cedraschi C, Hildebrandt J, Klaber-Moffett J, Kovacs F, Mannion AF, Reis $\mathrm{S}$, Staal JB, Ursin $\mathrm{H}_{\text {, }}$ Zanoli G. Chapter 4: European guidelines for the management of chronic nonspecific low back pain. Eur Spine 2006; 15:S192-S300.

40. Manchikanti L, Singh V, Pampati V, Smith HS, Hirsch J. Analysis of growth of interventional techniques in managing chronic pain in Medicare population: A 10-year evaluation from 1997 to 2006. Pain Physician 2009; 12:9-34.

41. Manchikanti L, Boswell MV. Interventional techniques in ambulatory surgical centers: A look at the new payment system. Pain Physician 2007; 10:627650.

42. Manchikanti L, Hirsch JA. Issues in Health Care: Interventional pain management at the crossroads. Health Policy Update. Pain Physician 2007; 10:261284.

43. West S, King V, Carey TS, Lohr KN, McKoy N, Sutton SF, Lux L. Systems to Rate the Strength of Scientific Evidence, Evidence Report, Technology Assessment No. 47. AHRO Publication No. 02E016. Rockville, MD: Agency for Health care Research and Quality, 2002. www. thecre.com/pdf/ahrq-system-strength. pdf

44. Atluri S, Datta S, Falco FJE, Lee M. Systematic review of diagnostic utility and therapeutic effectiveness of thoracic facet joint interventions. Pain Physician 2008; 11:611-629.

45. Singh V, Manchikanti L, Shah RV, Dunbar EE, Glaser SE. Systematic review of thoracic discography as a diagnostic test for chronic spinal pain. Pain Physician 2008; 11:631-642.

46. Manchikanti L, Dunbar EE, Wargo BW, Shah RV, Derby R, Cohen SP. Systematic Review of Cervical Discography as a Diagnostic Test for Chronic Spinal Pain. Pain Physician 2009; 12:305-321.

47. Wolfer L, Derby R, Lee JE, Lee SH. Systematic review of lumbar provocation discography in asymptomatic subjects with a meta-analysis of false-positive rates. Pain Physician 2008; 11:513-538.

48. Datta $S$, Lee M, Falco FJE, Bryce DA, Hayek SM. Systematic Assessment of Diagnostic Accuracy and Therapeutic Utility of Lumbar Facet Joint Interventions. Pain Physician 2009; 12:437460.

49. Falco FJE, Erhart S, Wargo BW, Bryce DA, Atluri S, Datta S, Hayek SM. Systematic Review of Diagnostic Utility and Therapeutic Effectiveness of Cervical Facet Joint Interventions. Pain Physician 2009; 12:323-344.

50. Smith HS, Chopra P, Patel VB, Frey ME,
Rastogi R. Systematic review on the role of sedation in diagnostic spinal interventional techniques. Pain Physician 2009; 12:195-206.

51. Berg AO, Allan JD. Introducing the third U.S. Preventive Services Task Force. Am J Prev Med 2001; 20:S3-S4.

52. Koes BW, Scholten RJ, Mens JM, Bouter LM. Efficacy of epidural steroid injections for low-back pain and sciatica: A systematic review of randomized clinical trials. Pain 1995; 63:279-288.

53. Helm S, Hayek $S$, Benyamin RM, Manchikanti L. Systematic review of effectiveness of thermal annular procedures in treating discogenic low back pain. Pain Physician 2009; 12:207232.

54. Conn A, Buenaventura RM, Datta S, Abdi S, Diwan S. Systematic review of caudal epidural injections in the management of chronic low back pain. Pain Physician 2009; 12:109-135.

55. Benyamin RM, Singh V, Parr AT, Conn A, Diwan S, Abdi S. Systematic review of the effectiveness of cervical epidurals in the management of chronic neck pain. Pain Physician 2009; 12:137-157.

56. Parr AT, Diwan S, Abdi S. Lumbar interlaminar epidural injections in managing chronic low back and lower extremity pain: A systematic review. Pain Physician 2009; 12:163-188.

57. Buenaventura RM, Datta S, Abdi S, Smith HS. Systematic review of therapeutic lumbar transforaminal epidural steroid injections. Pain Physician 2009; 12:233-251.

58. Epter RS, Helm S, Hayek SM, Benyamin RM, Smith HS, Abdi S. Systematic Review of Percutaneous Adhesiolysis and Management of Chronic Low Back Pain in Post Lumbar Surgery Syndrome. Pain Physician 2009; 12:361-378.

59. Hayek SM, Helm $S$, Benyamin RM, Singh V, Bryce DA, Smith HS. Effectiveness of Spinal Endoscopic Adhesiolysis in Post Lumbar Surgery Syndrome: A Systematic Review. Pain Physician 2009; 12:419-435.

60. Frey ME, Manchikanti L, Benyamin RM, Schultz DM, Smith HS, Cohen SP. Spinal Cord Stimulation for Patients with Failed Back Surgery Syndrome: A Systematic Review. Pain Physician 2009; 12:379-397.

61. Patel VB, Manchikanti L, Singh V, Schultz DM, Hayek SM, Smith HS. Systematic Review of Intrathecal Infusion Systems for Long-Term Management of Chronic 
Non-Cancer Pain. Pain Physician 2009; 12:345-360.

62. Guyatt G, Gutterman D, Baumann MH, Addrizzo-Harris D, Hylek EM, Phillips B, Raskob G, Lewis SZ, Schünemann $\mathrm{H}$. Grading strength of recommendations and quality of evidence in clinical guidelines. Report from an American College of Chest Physicians task force. Chest 2006; 129:174-181.

63. Dreyfuss $P$, Michaelsen M, Pauza $K$, McLarty J, Bogduk N. The value of medical history and physical examination in diagnosing sacroiliac joint pain. Spine 1996; 21:2594-2602.

64. Laslett M, Aprill CN, McDonald B, Young SB. Diagnosis of sacroiliac joint pain: A validity of individual provocation tests and composites of tests. Man Ther 2005; 10:207-218.

65. Young S, Aprill CN, Laslett M. Correlation of clinical examination characteristics with three sources of chronic low back pain. Spine J 2003; 3:460-465.

66. Maigne JY, Boulahdour $\mathrm{H}$, Chatellier $\mathrm{G}$. Value of quantitative radionuclide bone scanning in the diagnosis of sacroiliac joint syndrome in 32 patients with low back pain. Eur Spine J 1998; 7:328-331.

67. Slipman CW, Sterenfeld EB, Chou LH, Herzog R, Vresilovic E. The value of radionuclide imaging in the diagnosis of sacroiliac joint syndrome. Spine 1996; 21:2251-2254.

68. Broadhurst NA, Bond MJ. Pain provocation tests for the assessment of sacroiliac joint dysfunction. J Spin Disord 1998; 11:341-345.

69. Bogduk N. Pain provocation tests for the assessment of sacroiliac joint dysfunction. J Spinal Disord 1999; 12:357358.

70. Pang WW, Mok MS, Lin ML, Chang DP, Hwang MH. Application of spinal pain mapping in the diagnosis of low back pain - Analysis of 104 cases. Acta Anaesthesiol Sin 1998; 36:71-74.

71. Laslett M, Young SB, Aprill CN, MCDonald B. Diagnosing painful sacroiliac joints: A validity study of a McKenzie evaluation and sacroiliac provocation tests. Aust J Physiother 2003; 49:8997.

72. van der Wurff P, Buijs EJ, Groen GJ. A multitest regimen of pain provocation tests as an aid to reduce unnecessary minimally invasive sacroiliac joint procedures. Arch Phys Med Rehabil 2006; 87:10-14.
73. van der Wurff P, Buijs EJ, Groen GJ. Intensity mapping of pain referral areas in sacroiliac joint pain patients. J Manipulative Physiol Ther 2006; 29:190195.

74. Berthelot JM, Labat JJ, Le Goff B, Gouin $F$, Maugars $Y$. Provocative sacroiliac joint maneuvers and sacroiliac joint block are unreliable for diagnosing sacroiliac joint pain. Joint Bone Spine 2006; 73:17-23.

75. Simpson R, Gemmell H. Accuracy of spinal orthopaedic tests: A systemic review. Chiropr Osteopat 2006; 14:26.

76. Leboeuf $C$. The sensitivity and specificity of seven lumbo-pelvic orthopedic tests and the arm-fossa test. J Manip Physiol Ther 1990; 13:138-143.

77. Jung JH, Kim HI, Shin DA, Shin DG, Lee JO, Kim HJ, Chung JH. Usefulness of pain distribution pattern assessment in decision-making for the patients with lumbar zygapophyseal and sacroiliac joint arthropathy. J Korean Med Sci 2007; 22:1048-1054.

78. Puhakka KB, Jurik AG, Schiottz-Christensen $B$, Hansen GV, Egund N, Christiansen JV, Stengaard-Pedersen K. MRI abnormalities of sacroiliac joints in early spondyloarthropathy: A 1-year follow-up study. Scand I Rheumatol 2004, 33:332-338

79. Puhakka KB, Melson F, Jurik AG, Boel LW, Vesterby A, Egund N. MR imaging of the normal sacroiliac joint with correlation to histology. Skeletal Radiol 2004; 33:15-28.

80. Vogler JB 3rd, Brown WH, Helms CA, Genant HK. The normal sacroiliac joint: A CT study of asymptomatic patients. Radiology 1984; 151:433-437.

81. Elgafy $H$, Semaan $H B$, Ebraheim NA, Coombs RJ. Computed tomography findings in patients with sacroiliac pain. Clin Orthop Relat Res 2001; 382:112-118.

82. Dussault RG, Kaplan PA, Anderson MW. Fluoroscopy-guided sacroiliac joint injections. Radiology 2000; 214:273277.

83. Luukkainen RK, Wennerstrand PV, Kautiainen $\mathrm{HH}$, Sanila MT, Asikainen EL. Efficacy of periarticular corticosteroid treatment of the sacroiliac joint in non-spondylarthropathic patients with chronic low back pain in the region of the sacroiliac joint. Clin Exp Rheumatol 2002; 20:52-54.

84. Maugars $Y$, Mathis C, Berthelot JM, Charlier C, Prost A. Assessment of the efficacy of sacroiliac corticosteroid injections spondyloarthropathies: A double blind study. $\mathrm{Br} /$ Rheumatol 1996; 35:767-770.

85. Karabacakoglu A, Karakose S, Ozerbil OM, Odev K. Fluoroscopy-guided intraarticular corticosteroid injection into the sacroiliac joints in patients with ankylosing spondylitis. Acta Radiol 2002; 43:425-427.

86. Fischer T, Biedermann T, Hermann KG, Diekmann F, Braun J, Hamm B, Bollow $M$. Sacroiliitis in children with spondyloarthropathy: Therapeutic effect of CTguided intraarticular corticosteroid injection. Rofo 2003; 175:814-821.

87. Hanly JG, Mitchell M, MacMillan L, Mosher D, Sutton E. Efficacy of sacroiliac corticosteroid injections in patients with inflammatory spondyloarthropathy: Results of a 5 month controlled study. J Rheum 2000; 27:719-722.

88. Maugars $Y$, Mathis C, Vilon P, Prost A. Corticosteroid injection of the sacroiliac joint in patients with seronegative spondylarthropathy. Arthritis Rheum 1992; 35:564-568.

89. Bollow M, Braun J, Taupitz M, Haberle J, Reibhauer $\mathrm{BH}$, Paris $\mathrm{S}$, Mutze $\mathrm{S}$, Seyrekbasan F, Wolf KJ, Hamm B. CTguided intraarticular corticosteroid injection into the sacroiliac joints in patients with spondyloarthropathy: Indication and follow-up with contrast-enhanced MRI. / Comput Assist Tomogr 1996; 20:512-521.

90. Braun J, Bollow M, Seyrekbasan F, Haberle HJ, Eggens U, Mertz A, Distler A, Sieper J. Computed tomography guided corticosteroid injection of the sacroiliac joint in patients with spondyloarthropathy with sacroiliitis: Clinical outcome and follow-up by dynamic magnetic resonance imaging. J Rheumatol 1996; 23:659-664.

91. Luukkainen $R$, Nissila $M$, Asikainen E, Sanila M, Lehtinen K, Alanaatu A, Kautianen $\mathrm{H}$. Periarticular corticosteroid treatment of the sacroiliac joint in patients with seronegative spondyloarthropathy. Clin Exp Rheumatol 1999; 17:88-90.

92. Gunaydin I, Pereira PL, Daikeler T, Mohren M, Trubenbach J, Schick F, Kanz $L$, Kotter I. Magnetic resonance imaging guided corticosteroid injection of the sacroiliac joints in patients with therapy resistant spondyloarthropathy: A pilot study. I Rheumatol 2000; 27:424428.

93. Pereira PL, Gunaydin I, Duda SH, Tru- 
benbach J, Remy $\mathrm{CT}$, Kotter I, Kastler $B$, Claussen CD. Corticosteroid injections of the sacroiliac joint during magnetic resonance: Preliminary results [in French]. . Radiol 2000; 81:223-226.

94. Pereira PL, Gunaydin I, Trubenbach J, Dammann F, Remy CT, Kotter I, Schick F, Koenig CW, Claussen CD. Interventional MR imaging for injection of sacroiliac joints in patients with sacroiliitis. AJR Am J Roentgenol 2000; 175:265-266.

95. Ojala R, Klemola R, Karppinen J, Sequeiros RB, Tervonen O. Sacro-iliac joint arthrography in low back pain: Feasibility of MRI guidance. Eur J Radiol 2001; 40:236-239.

96. Slipman CW, Lipetz JS, Plastaras CT, Jackson HB, Vresilovic EJ, Lenrow DA, Braverman DL. Fluoroscopically guided therapeutic sacroiliac joint injections for sacroiliac joint syndrome. Am J Phys Med Rehabil 2001; 80:425-432.

97. Chakraverty R, Dias R. Audit of conservative management of chronic low back pain in a secondary care setting - Part I: Facet joint and sacroiliac joint interventions. Acupunct Med 2004; 22:207213.

98. Borowsky CD, Fagen G. Sources of sacroiliac region pain: Insights gained from a study comparing standard intraarticular injection with a technique combining intra- and peri-articular injection. Arch Phys Med Rehabil 2008; 89:2048-2056

99. Murakami E, Tanaka Y, Aizawa T, Ishizuka M, Kokubun S. Effect of periarticular and intraarticular lidocaine injections for sacroiliac joint pain: Prospective comparative study. J Orthop Sci 2007 12:274-280.

100. Ferrante $F M$, King LF, Roche EA, Kim PS, Aranda M, Delaney LR, Mardini IA, Mannes AJ. Radiofrequency sacroiliac joint denervation for sacroiliac syndrome. Reg Anesth Pain Med 2001; 26:137-142.

101. Gevargez A, Groenemeyer D, Schirp S, Braun M. CT-guided percutaneous radiofrequency denervation of the sacroiliac joint. Eur Radiol 2002; 12:13601365.

102. Cohen SP, Abdi S. Lateral branch blocks as a treatment for sacroiliac joint pain: A pilot study. Reg Anesth Pain Med 2003; 28:113-119.

103. Yin W, Willard F, Carreiro J, Dreyfuss P. Sensory stimulation-guided sacroiliac joint radiofrequency neurotomy: Technique based on neuroanatomy of the dorsal sacral plexus. Spine 2003;
28:2419-2425.

104. Buijs EJ, Kamphuis ET, Groen GJ. Radiofrequency treatment of sacroiliac joint-related pain aimed at the first three sacral dorsal rami: A minimal approach. Pain Clinic 2004; 16:139-146.

105. Burnham RS, Yasui Y. An alternate method of radiofrequency neurotomy of the sacroiliac joint: A pilot study of the effect of pain, function, and satisfaction. Reg Anesth Pain Med 2007; 32:12-19.

106. Vallejo R, Benyamin RM, Kramer J, Stanton G, Joseph NJ. Pulsed radiofrequency denervation for the treatment of sacroiliac joint syndrome. Pain Med 2006 7:429-434.

107. Cohen SP, Hurley RW, Buckenmaier CC 3rd, Kurihara C, Morlando B, Dragovich A. Randomized placebo-controlled study evaluating lateral branch radiofrequency denervation for sacroiliac joint pain. Anesthesiology 2008; 109:279-288

108. Kapural L, Nageeb F, Kapural M, Cata JP, Narouze S, Mekhail N. Cooled radiofrequency system for the treatment of chronic pain from sacroiliitis: The first case-series. Pain Pract 2008; 8:348354.

109. Harmon D, O'Sullivan M. Ultrasoundguided sacroiliac joint injection technique. Pain Physician 2008; 11:543547.

110. Manchikanti L, Singh V, Falco FJE, Cash KA, Pampati V. Effectiveness of thoracic medial branch blocks in managing chronic pain: A preliminary report of a randomized, double-blind controlled trial: Clinical Trial NCT00355706. Pain Physician 2008; 11:491-504.

111. Manchikanti L, Singh V, Falco FJ, Cash KA, Fellows B. Cervical medial branch blocks for chronic cervical facet joint pain: A randomized double-blind, controlled trial with one-year follow-up. Spine 2008; 33:1813-1820.

112. Manchikanti L, Singh V, Falco FJ, Cash KA, Pampati V. Lumbar facet joint nerve blocks in managing chronic facet joint pain: One-year follow-up of a randomized, double-blind controlled trial: Clinical Trial NCT00355914. Pain Physician 2008; 11:121-132.

113. Manchikanti L, Cash KA, McManus CD, Pampati V, Smith HS. Preliminary results of randomized, equivalence trial of fluoroscopic caudal epidural injections in managing chronic low back pain: Part 1. Discogenic pain without disc herniation or radiculitis. Pain Physician 2008; 11:785-800.

114. Manchikanti L, Singh V, Cash KA, Pampati V, Damron KS, Boswell MV. Preliminary results of randomized, equivalence trial of fluoroscopic caudal epidural injections in managing chronic low back pain: Part 2. Disc herniation and radiculitis. Pain Physician 2008; 11:801-815.

115. Manchikanti L, Singh V, Cash KA, Pampati V, Datta S. Preliminary results of randomized, equivalence trial of fluoroscopic caudal epidural injections in managing chronic low back pain: Part 3. Post surgery syndrome. Pain Physician 2008; 11:817-831.

116. Manchikanti L, Cash KA, McManus CD, Pampati V, Abdi S. Preliminary results of randomized, equivalence trial of fluoroscopic caudal epidural injections in managing chronic low back pain: Part 4. Spinal stenosis. Pain Physician 2008; 11:833-848.

117. Manchikanti L, Hirsch JA, Smith HS. Evidence-based medicine, systematic reviews, and guidelines in interventional pain management: Part 2: Randomized controlled trials. Pain Physician 2008; 11:717-773.

118. Altman DG, Schulz KF, Moher D, Egger M, Davidoff F, Elbourne D, Gøtzsche PC, Lang T; CONSORT GROUP (Consolidated Standards of Reporting Trials). The revised CONSORT statement for reporting randomized trials: Explanation and elaboration. Ann Intern Med 2001; 134:663-694.

119. Boswell MV, Colson JD, Sehgal N, Dunbar E, Epter R. A systematic review of therapeutic facet joint interventions in chronic spinal pain. Pain Physician 2007; 10:229-253.

120. Manchikanti L, Boswell MV, Singh V, Pampati V, Damron KS, Beyer CD. Prevalence of facet joint pain in chronic spinal pain of cervical, thoracic, and lumbar regions. BMC Musculoskelet Disord 2004; 5:15.

121. Manchukonda R, Manchikanti KN, Cash KA, Pampati V, Manchikanti L. Facet joint pain in chronic spinal pain: An evaluation of prevalence and false-positive rate of diagnostic blocks. J Spinal Disord Tech 2007; 20:539-545.

122. Manchikanti L, Cash KA, Pampati V, Fellows $B$. Influence of psychological variables on the diagnosis of facet joint involvement in chronic spinal pain. Pain Physician 2008; 11:145-160. 
123. Manchikanti L, Manchikanti K, Cash KA, Singh V, Giordano J. Age-related prevalence of facet joint involvement in chronic neck and low back pain. Pain Physician 2008; 11:67-75.

124. Manchikanti L, Boswell MV, Manchukonda R, Cash KA, Giordano. Influence of prior opioid exposure on diagnostic facet joint nerve blocks. J Opioid Manage 2008; 4:351-360.
125. Cohen SP. Epidemics, evolution and SI joint pain. Reg Anesth Pain Med 2007; 32:3-6.

126. Cohen SP, Strassels S, Kurihara $C$, Crooks MT, Bleckner LL, Forsythe A, Marcuson M. Outcome predictors for sacroiliac (lateral branch) radiofrequency denervation. Reg Anesth Pain Med 2009; in press.
127. Dreyfuss $P$, Henning $T$, Malladi R, Goldstein B, Bogduk N. The ability of multisite, multi-depth sacral lateral branch blocks to anesthetize the sacroiliac joint complex: A physiologic study. Presented at International Spinal Intervention Society 16th Annual Meeting, Las Vegas, NV, July 23-26, 2008. 